\title{
Enterprise Combination in Livestock Sector in Southwestern, Nigeria
}

\author{
Olasunkanmi Moses Bamiro ${ }^{1}$, Israel Ajibade Adedeji ${ }^{1,}$, , Abiodun Olarewaju Otunnaiya ${ }^{2}$, \\ Wale Soluade $^{2}$, Joseph Olufemi Ogunjobi ${ }^{1}$ \\ ${ }^{1}$ Department of Agricultural Economics and Extension, Landmark University, Omu-Aran, Nigeria \\ ${ }^{2}$ Department of Agricultural Economics and Farm Management, Olabisi Onabanjo University, Yewa Campus, Ayetoro, Nigeria
}

Email address:

ajibby77@gmail.com (I. A. Adedeji)

To cite this article:

Olasunkanmi Moses Bamiro, Israel Ajibade Adedeji, Abiodun Olarewaju Otunnaiya, Wale Soluade, Joseph Olufemi Ogunjobi. Enterprise Combination in Livestock Sector in Southwestern, Nigeria. Journal of World Economic Research. Vol. 4, No. 2, 2015, pp. 38-44.

doi: $10.11648 /$ j.jwer.20150402.13

\begin{abstract}
This study examined the optimal combination of enterprises in livestock industry in South-West Nigeria. Stratified random sampling technique was employed in collecting data from 360 livestock farmers. Descriptive statistics, budgetary technique and linear programming model were employed for data analysis. Six livestock enterprises, non-integrated poultry, piggery and fishery and horizontally integrated poultry/fishery, poultry/piggery and poultry/piggery/fishery were identified. Livestock farmers in the area are aged with low level of education and large household size do not operate at optimal level based on the available resources. The budgetary analysis shows that the most profitable enterprise combination is integrated poultry and piggery while the enterprise that yielded the least net farm income is non-integrated poultry enterprise. The profitability of integrated and non-integrated livestock enterprises is limited by high cost of production in which the feed cost constitutes the lion's share. The optimal enterprise combinations are the integrated poultry and fishery and integrated poultry/piggery enterprise with poultry/piggery combination being the most efficient. The policy implication from this study requires that both farmers and government must team up to find a means of reducing feed cost by financing livestock research centers and state agricultural development programmes to develop genetically improved breeds of livestock which efficiently converts feed. Labour as a resource was the most limited in the area, there is therefore the need for research to focus critically on indigenously automated livestock equipment that can perform tasks like feeding, vaccination, etc. Farmers in South-West Nigeria and by extension, Nigeria as a whole should concentrate and intensify their livestock combination practices especially that of poultry/piggery, which is the optimal combination enterprise and that of poultry/fishery enterprise combination because of their high profitability levels.
\end{abstract}

Keywords: Livestock, Optimal, Enterprise, Combination, Linear Programming

\section{Introduction}

The livestock sector accounts for one third of Nigeria's agricultural GDP thereby playing a vital socio-economic role in the Nigerian economy. The traditional livestock industry in Nigeria is noted for providing income, employment, farm energy, manure, transport, food for human consumption and fuel for the domestic industries. They are also a major source of government revenue. The continuous population growth, with the accompanying accelerated rural-urban migration and rise in living standards has resulted tremendous increase in demand for livestock. Majority of Nigerians consume one livestock product or the other, even though per capita protein consumption level is considered low (Mbanasor and Nwosu, 2003).

Livestock production provides a means of boosting the farm business into balance with the management that is available. The kinds and amount of livestock should be adapted to the managerial efficiency and capacity. With a high level of managerial ability, a large amount of livestock may be profitably added to a farm; however, with poor management, livestock may reduce the profitability of the farming operations.

The livestock sector plays a vital socio-economic role in 
the Nigerian economy. The animals provide the best type of protein for human consumption, as compared to crops, yet, it is hardly available and in most of the cases it is not affordable by the common man. A majority of Nigerians consume one livestock product or the other, even though per capita protein consumption is considered low. Livestock production has not kept pace with consumption. This increasing gap between demand and supply has led to a steep rise in prices of livestock and livestock products (Mbanasor and Nwosu, 2003).

In Nigeria, the supply of meat falls short of demand. Most Nigerians are poorly fed and suffer from malnutrition due to lack of adequate protein of animal source (Ajala and Alli-Balogun, 2004). In a nutritional profile of Nigeria, FAO (1990) reported that the protein supply per capita was 44 gram, out of which, animal product constituted less than $2 \%$. With the continued rise in the cost of production of beef, mutton and chicken which are the primary sources of animal protein in Nigeria, it has become very necessary to explore other efficient and less common but potential sources of animal protein for economic viability. Ademosun (1999) pointed out that the present average level of protein consumption per capita in Kwara state is less than $7.5 \mathrm{~g}$. This according to his study is in line with most states of the federation. Despite the importance of livestock in the economy and the large number of the different species, Nigeria has not been able to provide animal protein sufficient in quantity to meet the per capita animal protein requirement of the citizenry (Onuekwusi, 2001). The average Nigerian consumes only about $7 \mathrm{~g}$ of animal protein daily and this represents a shortfall of $75 \%$ (Ibe, 1999).

Livestock farming in Nigeria is characterized by mixed farming. Several farmers diversify with the aim to reduce risk and increase profitability. According to KayRonald (1981) many business firms diversify or produce more than one product to avoid having their income totally dependent on the production and price of one product. It is assumed that if profit from one enterprise is poor, profit from producing and selling other products may prevent total profit from falling below acceptable levels. In agricultural production, diversification or enterprise combination may reduce income variability if all prices and yields are not low or high at the same time (Bamiro, 2007). The principles of enterprise combination in farm management is often confronted with the problem of what enterprise should take up, how far should we go in combining the enterprise with another or replacing an enterprise, depend partly on the interrelationship between different enterprises and the price of products and inputs (Adejobi and Kormawa, 2003).

Further to the above problems on protein sources, it is a known fact that a typical farmer anywhere in the world has limited level of resources. He is faced with the problem of myriads of choices for allocating farm resources between the different livestock enterprises so as to optimize production objectives by making efficient utilization of the available resources and combining the enterprises in an optimal manner. Identifying the best farm plan is a difficult task for small scale farmers with low level of literacy (Ohajianya and Oguoma, 2009).

The integrated enterprise which will offer farmers the desired results is a decision they often take by trial and error method, the outcome of which is usually uncertain. This study therefore, seeks to determine the cost and returns as well as the most profitable combination of enterprises as well as efficiency of productive resources in Southwestern, Nigeria.

\section{Methodology}

This study was conducted in South Western Nigeria. Data were collected from livestock farmers in four States using a multistage sampling technique. Budgetary technique, linear programming and stochastic production frontier were employed for gross margin analysis, optimal combination of resources and productive efficiency analysis respectively.

\subsubsection{Budgetary Analysis}

The type of budgetary analyses that were employed to determine resource productivity on the farm are the gross margin analysis and Net Farm Income analysis.

\section{(i). Gross Margin Analysis}

$$
\mathrm{GM}=\mathrm{TR}-\mathrm{TVC}
$$

Where,

$\mathrm{GM}=$ Gross margin per month $(\mathrm{N})$

$\mathrm{TR}=$ Total Revenue per month $(\mathrm{N})$

$\mathrm{TVC}=$ Total variable cost $(\mathrm{N})$

\section{(ii). Net Farm Income Analysis}

$$
\mathrm{NFI}=\mathrm{TR}-\mathrm{TC}
$$

Where,

$\mathrm{NFI}=$ Net Income per month $(\mathrm{N})$

$\mathrm{TC}=$ Total $\operatorname{cost}(\mathrm{N})$

\subsubsection{Linear Programming Techniques}

Linear programming tools find easy application in optimization problem, where the aim is to maximize or minimize a linear objective function subject to a set of linear constraints. For optimal livestock combination problem, the linear programming is considered appropriate because the farmer is interested in a livestock combination that maximizes his or her gross margin. Thus, the solution of the linear program matrix represents the profit maximizing livestock combination and this solution can be tested for changes in resource availability under alternative livestock combination. This same technique was utilized by Adesiyan et al (2004), Bamiro et al (2012) in order to achieve their objectives. In using this techniques, certain assumptions have to be satisfied, these includes: Additivity and Linearity, divisibility, finiteness and certainty. The linear programming model is specified thus: The problem is to maximize an objective function subject to the limitation of certain constraints. 


$$
\operatorname{Max} Z=\Sigma c j x j=C_{1} X_{1}+C_{2} X_{2}+\ldots \ldots \ldots \ldots+C_{n} X_{n}
$$

Subject to:

$$
\begin{gathered}
A_{11} X_{1}+A_{12} X_{2}+\ldots \ldots \ldots \ldots+A_{1 n} X_{n}=B_{1} \\
A_{21} X_{1}+A_{22} X_{2}+\ldots \ldots \ldots \ldots+A_{2 n} X_{n}=B_{2} \\
A_{m 1} X_{1}+A_{m 2} X_{2}+\ldots \ldots \ldots \ldots .+A_{m n} X_{n}=B_{n}
\end{gathered}
$$

$\mathrm{X}_{1}, \mathrm{X}_{2}, \ldots \ldots \ldots \ldots \mathrm{X}_{\mathrm{n}}>0$ i.e Non-negativity restrictions

Where;

$\mathrm{Z}=$ The objective function (gross margin)

$\mathrm{m}=$ Number of resources

$\mathrm{n}=$ Number of activities

$\mathrm{Cj}=$ Net price/unit of activity(contribution of $\mathrm{Z}$ for each unit of activity $\mathrm{j}$ for $\mathrm{j}=1,2, \ldots \mathrm{n}$ )

$\mathrm{Xj}=$ level at which activity is to be produced/number of units of activity $j$, for $j=1,2, \ldots . n$

$\mathrm{B}_{\mathrm{i}}=$ Amount or resources available for $\mathrm{i}=1,2, \ldots \ldots \ldots \ldots \mathrm{m}$

$A_{i j}=$ Amount of $i$ th resource consumed by each unit of activity j.

Subject to $\mathrm{m}$ constraints which can be express as follows:

Activities in the model: the livestock enterprise combinations are:

$\mathrm{X}_{1}=$ poultry

$\mathrm{X}_{2}=$ fishery

$\mathrm{X}_{3}=$ piggery

$\mathrm{X}_{4}=$ poultry/fishery

$\mathrm{X}_{5}=$ poultry/piggery

$\mathrm{X}_{6}=$ poultry/piggery/fishery

The constraints are:

- Labour constraint

- Capital constraint

- $\quad$ Feed constraint

\subsubsection{Cobb-Douglas Stochastic Production Frontier Technique}

The explicit form of the production function is specified below:

$$
\operatorname{InY}=\alpha_{0}+\alpha_{1} \operatorname{LnX}_{1}+\alpha_{2} \operatorname{LnX}_{2}+\alpha_{3} \operatorname{LnX}_{3}+\alpha_{4} \operatorname{LnX}_{4}+U
$$

where

$\mathrm{Y}=$ farm output (total value of animals on the farm in

$\mathrm{X}_{1}=$ Labour in man-days

$\mathrm{X}_{2}=$ quantity of feed cost in

$\mathrm{X}_{3}=$ cost of medication in

$\mathrm{X}_{4}=$ capital in

$\alpha_{1-5}=$ coefficients to be estimated.

$\mathrm{U}=$ error term.

In = Logarithm to base e.

Inefficiency variables

$\mathrm{Z}_{1}=$ age in years

$Z_{2}=$ Sex $($ male $=1$, female $=0)$

$\mathrm{Z}_{3}=$ Marital status $($ married $=1$, single $=0$ )

$\mathrm{Z}_{4}=$ years of farming experience

$Z_{5}=$ household size (number)

$\mathrm{Z}_{6}=$ major occupation (farming $=1$, others $=0$ )

\section{Results and Discussion}

Table 1 shows the distribution of the socio economic characteristics of the livestock farmers and their households. The results show that most of the livestock farmers' age range between 30 and 60 years but the modal age is 45 years. Several of them have formal education with relevant farming experience that spans between 6 and 20 years, a combination that is expected to culminate to high productivity and efficiency in the management roles of the farmers. There are six livestock enterprises (poultry, piggery, fishery, poultry/fishery; poultry/piggery and poultry/piggery/fishery) that are identified in the study area. Majority of the livestock

\begin{tabular}{|c|c|c|}
\hline Characteristics & Frequency & Percentage \\
\hline \multicolumn{3}{|l|}{ Age (Years) } \\
\hline Below 30 & 54 & 15.0 \\
\hline $31-40$ & 90 & 25.0 \\
\hline $41-50$ & 102 & 28.3 \\
\hline $51-60$ & 78 & 21.7 \\
\hline Above 60 & 36 & 10.0 \\
\hline \multicolumn{3}{|l|}{ Level of Education } \\
\hline No formal education & 36 & 1.0 \\
\hline Primary school & 54 & 15.0 \\
\hline Secondary school & 117 & 32.5 \\
\hline $\mathrm{NCE} / \mathrm{OND}$ & 147 & 40.8 \\
\hline University & 6 & 1.7 \\
\hline \multicolumn{3}{|l|}{ Years of Experience } \\
\hline 0 & 15 & 42.0 \\
\hline$<5$ & 141 & 39.2 \\
\hline $6-10$ & 138 & 38.3 \\
\hline $11-15$ & 39 & 10.8 \\
\hline $16-20$ & 9 & 9.2 \\
\hline Above 20 & 18 & 5.0 \\
\hline \multicolumn{3}{|l|}{ Major Occupation } \\
\hline Farming & 234 & 65.0 \\
\hline Trading & 36 & 10.0 \\
\hline Civil servants/paid workers & 90 & 25 \\
\hline \multicolumn{3}{|l|}{ Livestock Combination } \\
\hline Poultry only & 93 & 25.8 \\
\hline Fishery only & 96 & 26.7 \\
\hline Piggery only & 42 & 11.7 \\
\hline Poultry/Fishery & 42 & 11.7 \\
\hline Poultry/Piggery & 30 & 8.3 \\
\hline Poultry/Piggery/Fishery & 57 & 15.8 \\
\hline
\end{tabular}
farmers (64.2 percent) did not combine the livestock enterprises rather they operated them separately.

Table 1. Socio-economic Characteristics of Livestock Farmers in South-West, Nigeria.

Table 2 indicates the result of the costs and returns structure of an average integrated livestock farm. The result shows that an average farmer invested $\$ 2,908,079,60$ in the enterprise. This comprises of costs of stocks, feed, drugs and other necessary items including the cost of labour input. Cost of feed $(\$ 2,751,740.20)$ constitute the greatest share of the total cost of production representing $54.62 \%$. This large percentage shows the importance of feed availability and affordability if livestock production is to be improved. Cost 
of stock was next in value to feed cost in livestock production accounting for about $21 \%$ of total cost. Other cost components are labour vaccination and veterinary services.

Table 2. Average costs and returns to livestock farms in the area.

\begin{tabular}{lll}
\hline Description & Value (N) & $\begin{array}{l}\text { Cost components } \\
\text { as \% of TC }\end{array}$ \\
\hline Depreciation on building & $36,756.15$ & 5.61 \\
Depreciation on barrow & 497.83 & 1.26 \\
Depreciation on borehole & $6,644.94$ & 0.2 \\
Depreciation on generator & $5,354.79$ & 2.3 \\
Depreciation on shovel & 308.78 & 1.8 \\
Depreciation on machine & $4,216.37$ & 0.1 \\
Depreciation on scale & 899.40 & 1.4 \\
Tax & 725.00 & 0.2 \\
Total Fixed Cost & $55,403.25$ & 11.91 \\
cost of stock & $7,810.03$ & 20.7 \\
Wage/manday & $68,962.50$ & 2.7 \\
cost of vaccination & $9,321.25$ & 3.2 \\
cost Drug & $1,480.25$ & 0.8 \\
Veterinary service & $3,720.25$ & 2.3 \\
Water bill & $1,530.58$ & 0.8 \\
Electricity bill & $1,376.67$ & 0.6 \\
Transport cost & $6,734.58$ & 2.3 \\
cost of feed & $2,751,740.21$ & 54.62 \\
Total Variable Cost & $2,852,676.33$ & 88.09 \\
Total Cost & $2,908,079.57$ & \\
Revenue from birds & $1,085,324.94$ & 31.79 \\
Revenue from eggs & $929,346.54$ & 27.22 \\
Revenue from fish & $254,495.42$ & 7.45 \\
Revenue from Pig & $1,144,911.83$ & 33.54 \\
Total Revenue & $3,414,078.73$ & \\
Gross Margin & $561,402.40$ & \\
Net farm income (NFI) & $505,999.16$ & \\
Profitability Analysis & 0.75 & \\
Profitability index (PI) & 0.21 & \\
Operating ratio & 79.8 & \\
Rate of return on investment (RRI) & & \\
\hline & & \\
\hline
\end{tabular}

The results in the Table 2 further shows that total revenue of $\$ 3,414,078.73$ was earned by an average livestock farmer during the period. Three profitability indicators estimated are gross margin ( $\$ 561,402.40)$, net farm income ( $\$ 505,999.16$ ). The profitability index is 0.75 which implies that for every naira sales, 75 kobo was earned while the rate of investment is $79.8 \%$, signifying that about $80 \mathrm{kobo}$ accrued to the farmers from every naira invested in livestock enterprise. The operating ratio indicates that the total variable cost is about $21 \%$ of the total revenue.

The cost-return structure of the livestock industry was further examined on the basis of each enterprise and enterprise combinations to ascertain the most profitable enterprise and vise-versa. The results are presented in Table 3. This result indicates that farmers involved in sole poultry production are likely to encounter problems in terms of the ease of conversion into other combinations since they have a very high percentage of fixed cost. The most flexible is sole fishery production enterprise with the least percentage of fixed cost. The result further shows that cost of feed takes the lion share in all combinations.

The linear programming model result shows that only enterprises $\mathrm{X}_{4}$ (poultry/fish) and $\mathrm{X}_{5}$ (poultry/pig) entered the final livestock plan/solution. The optimal value of the linear programming solution is $\$ 214,586,446$. This is the value of the programme which was obtained by using $124.51 \mathrm{~kg}$ of feed for poultry/fish enterprise and $38.73 \mathrm{~kg}$ of feed for poultry/pig enterprise at a gross margin of $\$ 171,445,181.97$ and $\$ 43,141,264.13$ respectively.

\subsection{Discussion}

This cost-return structure results presented in Tables 2 and 3 compares favourably with the findings of Olawunmi et al, (2010) on poultry production and Bamiro et al, (2012) on fish production. They both affirmed that feed cost is the major important single cost item associated with livestock production due to the increased cost of feed ingredients such as maize, groundnut cake, soyabean mesh and scarcity of wheat and corn offal.

In summary, all the profitability indicators show that livestock enterprise is profitable in the study area. The various profitability analyses conducted across the combinations shows that it is more profitable to combine two different livestock in order to maximize profit. In terms of gross margin and net farm income, poultry/piggery production recorded the highest value in each category, followed by poultry/fishery and the least is recorded by sole poultry enterprise.

\subsection{Optimal Combination of the Livestock Enterprises}

The linear programming matrix was constructed based on the six identified prominent livestock enterprises in the area. The matrix shows the enterprises gross margin, the available resources and the used resources. The linear programme was analysed using "Tora" software programme. The solution of the linear programme is presented in the table below.

Enterprises $\mathrm{X}_{1}, \mathrm{X}_{2}, \mathrm{X}_{3}$, and $\mathrm{X}_{6}$ did not enter the final plan, since they have non-zero opportunity cost indicating that these enterprises were not in the best competitive positions as compared to enterprises $\mathrm{X}_{4}$ and $\mathrm{X}_{5}$. This result further corroborates the result of the gross margin analysis conducted for each enterprise and shows that the best/optimal enterprise combination which is capable of maximizing net farm income in livestock industry in the study area is poultry/fish and poultry/pig enterprises.

The opportunity cost of the excluded enterprises are $\$ 2,861,062.33$ for poultry, $\$ 1,383,632$ for fish, $\$ 1,191,220.33$ for pig and $\$ 2,422,781.33$ for poultry/fish/pig enterprise combinations. The included enterprises $\left(\mathrm{X}_{4}\right.$ and $\left.\mathrm{X}_{5}\right)$ have zero opportunity cost. This result indicates that by forcing any of the excluded enterprises for instance, $X_{1}$ (poultry enterprise) into the programme, it is capable of reducing the value of the programme by $\$ 2,861,062.33$. This implication is similar for other excluded variables in the programme.

The opportunity cost of resources used in livestock production in the area indicates that feed and labour are the 
only limiting resources. Capital is a non-limiting resource in livestock production in the area. There was $\$ 53,478,853.25$ of unused capital in the area.

The shadow price of feed is $\$ 37,533.57$ indicating that by increasing the quantity of feed available by $1 \mathrm{~kg}$, the gross margin would increase by $¥ 37,533.57$. Also, the shadow price of labour was $\$ 877,313.33$ indicating that by increasing labour by one manday, the gross margin would increase by \#87,313.33. The result implies possibly that for optimal livestock production, feed and labour use should be increased since capital is not limited, so, increased in quantity of feeds per animal and number of labour would increase livestock production in the area.

\section{Conclusion and Recommendations}

Livestock farmers in the area are aged with low level of education and large household size. The study reveals that farmers in the study area are not operating at optimal level based on the available resources. These resources are not efficiently allocated in terms of inputs as seen in the optimal plan. Further, the resource use allocation in the study depicts that since the household held some resources in excess, it is an indication of inefficiency in actual resource use by the households in their livestock enterprise. The study further shows that the best enterprise combinations in the study area are the poultry/piggery followed by poultry/fishery. However the profitability of livestock enterprises is limited by high cost of production in which the feed cost constitutes the lion's share. Finally, the result suggested that although an average livestock farmer in the area records a large amount of profit, they exhibit a relatively high level of inefficiency due to technical knowhow.

On the premise of these findings, both farmers and government must team up to find a means of reducing feed cost. Some ways of achieving these is for the government to subsidize livestock production by setting up livestock research centers and state agricultural development programmes to develop genetically improved breeds of livestock which efficiently converts feed. There is need for research to focus critically on indigenously automated livestock equipment that can reduce the work load during feeding and other health management activity. Livestock farmers should adopt cost and risk reduction strategy known as enterprise combination and increase their stock number supplying them with quality feeds so as to foster increased efficiency in livestock production. Livestock farmers in South-West Nigeria and by extension in Nigeria as a whole should concentrate and intensify their livestock combination practices with poultry/piggery, which is the most efficient and optimal combination enterprise followed by poultry/fishery enterprise combination because of their high profit margin as compare to any other livestock combination farming system.

Table 3. Cost-Return Structure of Enterprise Combinations in Livestock Industries in South-West Nigeria.

\begin{tabular}{|c|c|c|c|c|c|c|}
\hline Description & $\begin{array}{l}\text { Sole Poultry } \\
\text { (A) }\end{array}$ & $\begin{array}{l}\text { Sole Fishery } \\
\text { (A) }\end{array}$ & $\begin{array}{l}\text { Sole Piggery } \\
\text { (A) }\end{array}$ & $\begin{array}{l}\text { Poultry/fish } \\
\text { (N) }\end{array}$ & $\begin{array}{l}\text { Poultry/piggery } \\
\text { (A) }\end{array}$ & $\begin{array}{l}\text { Poutry/fish/pig } \\
\text { (A) }\end{array}$ \\
\hline Depreciation on building & 5577.20 & $11,158.23$ & $16,142.50$ & $41,313.16$ & $8,531.91$ & $11,532.01$ \\
\hline Depreciation on barrow & 814.63 & 0.00 & 837.50 & 507.73 & $1,415.33$ & 78.95 \\
\hline Depreciation on borehole & 12178.47 & $7,000.00$ & $2,147.38$ & 15.71 & $3,920.67$ & $6,650.72$ \\
\hline Depreciation on generator & 7846.06 & 0.00 & $1,880.95$ & $5,086.73$ & $23,432.14$ & $3,551.44$ \\
\hline Depreciation on shovel & 174.20 & 0.00 & 869.64 & 15.71 & $1,228.33$ & 367.11 \\
\hline Depreciation on machine & 10645.16 & 0.00 & 0.00 & $12,551.02$ & 0.00 & 13.16 \\
\hline Depreciation on scale & 806.18 & 75.00 & $2,595.83$ & 956.70 & $2,975.00$ & 55.26 \\
\hline Tax & 0.00 & 0.00 & 0.00 & 785.71 & $7,000.00$ & 315.79 \\
\hline Total Fixed Cost & $38,041.89$ & $18,233.43$ & $24,473.81$ & $61,232.49$ & $48,503.38$ & $22,564.44$ \\
\hline cost of stock & $2,079.60$ & $9,734.56$ & $4,027.14$ & $12,920.68$ & $22,951.50$ & $4,970.84$ \\
\hline wage/manday & $8,209.68$ & $7,281.25$ & $2,250.00$ & $36,000.00$ & $25,600.00$ & $8,447.37$ \\
\hline cost of vaccination & $5,458.87$ & 0.00 & 0.00 & $8,285.71$ & $7,710.00$ & $5,064.47$ \\
\hline Cost Drug & 0.00 & $1,250.00$ & 0.00 & $9,830.71$ & 0.00 & 0.00 \\
\hline Veterinary service & $5,767.42$ & 687.50 & $6,478.57$ & 0.00 & 0.00 & $8,154.74$ \\
\hline Water bill & 158.06 & $3,125.00$ & $2,62.14$ & $1,371.43$ & $1,850.00$ & 236.84 \\
\hline Electricity bill & 837.10 & 93.75 & $2,214.29$ & $4,028.57$ & $3,610.00$ & 671.05 \\
\hline Transport cost & $3,319.35$ & 109.38 & $2,778.57$ & $4,071.43$ & $54,935.00$ & $2,973.68$ \\
\hline cost of feed & $20,375.00$ & $224,343.75$ & $239,306.43$ & $140,981.54$ & $119,927.6$ & $91,901.58$ \\
\hline Total Variable Cost & $46,205.08$ & $246,625.19$ & $259,667.14$ & $217,490.07$ & $236,584.1$ & $122,420.58$ \\
\hline Total Cost & $84,246.97$ & $264,858.62$ & $284,140.95$ & $278,722.56$ & $285,087.51$ & $144,985.02$ \\
\hline Revenue from birds & $70,483.87$ & 0.00 & 0.00 & $205,000.00$ & $63,264.95$ & $286,481.47$ \\
\hline Revenue from eggs & $76,827.74$ & 0.00 & 0.00 & $298,000.00$ & $509,827.8$ & $18,755.00$ \\
\hline Revenue from fish & 0.00 & $631,714.06$ & 0.00 & $236,258.60$ & 0.00 & $18,947.37$ \\
\hline Revenue from Pig & 0.00 & 0.00 & $668,550.00$ & 0.00 & $260,000.0$ & $57,684.21$ \\
\hline Total Revenue & $147,311.61$ & $631,714.06$ & $668,550.00$ & $739,258.86$ & $833,092.7$ & $381,868.05$ \\
\hline Gross Margin & $101,106.53$ & $385,088.87$ & $408,882.86$ & $521,768.53$ & $596,508.6$ & $259,447.47$ \\
\hline Net farm income & $63,064.64$ & $366,855.44$ & 384409.05 & $460,536.30$ & $548,005.2$ & $236,883.03$ \\
\hline \multicolumn{7}{|l|}{ Profitability Analysis } \\
\hline Profitability index (PI) & 0.43 & 0.58 & 0.53 & 0.63 & 0.66 & 0.62 \\
\hline Operating ratio & 0.31 & 0.39 & 0.41 & 0.29 & 0.28 & 0.32 \\
\hline Rate of return on investment $(\%)$ & 174.86 & 238.51 & 222.78 & 265.23 & 292.22 & 263.38 \\
\hline
\end{tabular}


Table 4. Linear programming matrix.

\begin{tabular}{lllllll}
\hline Program matrix & & & & & \\
\hline & Poultry & Fish & Pig & Poultry/fish & Poultry/pig & Poultry/fish/pig \\
\hline & $\mathbf{X}_{\mathbf{1}}$ & $\mathbf{X}_{\mathbf{2}}$ & $\mathbf{X}_{\mathbf{3}}$ & $\mathbf{X}_{\mathbf{4}}$ & $\mathbf{X}_{\mathbf{5}}$ & $\mathbf{X}_{\mathbf{6}}$ \\
\hline $\begin{array}{l}\text { Maximize } \\
\text { Subject to }\end{array}$ & 182829.00 & 256558.00 & 10203.00 & 1376996.00 & 1113802.00 & 357916.00 \\
Feed(Kg) & 25.00 & 25.00 & 25.00 & 25.00 & 25.00 & 25.00 \\
Labour(mandays) & 2.40 & 0.80 & 0.30 & 0.50 & 0.20 & 2.10 \\
Capital (N) & 9503.00 & 4355.00 & 1067.00 & 91262.00 & 4090.00 & 51138.00 \\
\hline
\end{tabular}

Table 5. Linear programming output summary.

\begin{tabular}{llll}
\hline $\begin{array}{l}\text { Final Iteration } \\
\text { Objective Value }=\mathbf{2 1 4 5 8 6 4 4 6 . 1 1}\end{array}$ & & & \\
\hline Variable & Value & Objective Coefficient & Objective Value Contribution \\
\hline $\mathrm{X}_{1}$ : poultry & 0.00 & 182829.00 & 0.00 \\
$\mathrm{X}_{2}$ : fish & 0.00 & 256558.00 & 0.00 \\
$\mathrm{X}_{3}$ : pig & 0.00 & 10203.00 & 0.00 \\
$\mathrm{X}_{4}$ : poultry/fish & 124.51 & 1376996.00 & 171445181.97 \\
$\mathrm{X}_{5}:$ poultry/pig & 38.73 & 1113802.00 & 43141264.13 \\
$\mathrm{X}_{6}:$ poultry/fish/pig & 0.00 & 357916.00 & 0.00 \\
Constraints $_{\text {feed }(<)}$ & RHS & Slack-/Surplus + & \\
labour $(<)$ & 4081.00 & 0.00 & \\
capital $(<)$ & 70.00 & 0.00 & \\
\hline
\end{tabular}

Table 6. Sensitivity Analysis.

\begin{tabular}{llll}
\hline Variable & Current Obj coeff & Min Obj Coeff & Max Obj Coeff \\
\hline $\mathrm{X}_{1}:$ poultry & 182829.00 & -infinity & 3043891.33 \\
$\mathrm{X}_{2}:$ fish & 256558.00 & - infinity & 1640190.00 \\
$\mathrm{X}_{3}:$ pig & 10203.00 & - infinity & 1201533.33 \\
$\mathrm{X}_{4}:$ poultry/fish & 1376996.00 & 1113802.00 & - infinity \\
$\mathrm{X}_{5}:$ poultry/pig & 1113802.00 & 550798.40 & 1376996.00 \\
$\mathrm{X}_{6}:$ poultry/fish/pig & 357916.00 & - infinity & 2780697.33 \\
Constraints & Current RHS & Min RHS & Max RHS \\
feed $(<)$ & 4081.00 & 3500.00 & 8750.00 \\
labour $(<)$ & 70.00 & 32.65 & 81.62 \\
capital $(<)$ & 65000000.00 & -infinity & 0.00 \\
\hline
\end{tabular}

[6] Bamiro O.M (2007): Effects of vertical integration and Enterprise combinations Profitability in the Poultry Industry in Ogun and Oyo states of Nigeria. Agricultural Journal; 2(3): 397-404.

[1] Adejobi A.P., Kormawa O. P (2003): Optimal crop combination smallholder farmer a Linear Programme Analysis. Journal of Economics and Social Studies; 2(4): 201-204.

[2] Ademosun A.A (1999): The livestock sub-sector in the third national development plan. Nigerian Journal of Animal Production; 3(3):10-17.

[3] Adesiyan O.I. ET AL. (2004): Optimum Enterprise Combination in Maize farm in Orire Local Government Area of Oyo state Nigeria. Pakistan Journal of Social Science; 4(2): 275-278.

[4] Ajala, M.K., Alli-Balogun J.K (2004): Economics of rabbit production in Zaria, Kaduna state, Nigeria. Tropical Journal of Animal Science; 7:1-10.

[5] Bamiro O.M. ET AL. (2012): Economics of Horizontal Integration in Poultry Industry in South-West Nigeria International Journal of Poultry Science; 11(1): 36-49.
[7] Bamiro O.M. ET AL. (2012): Enterprise Combinations in Cassava based Food Crop Farming System in Nigeria: Evidence from Ogun State Greener Journal of Agricultural Sciences; 2(1): 13-20.

[8] FAO (1990): Food and Agriculture Organization Nutritional Profile. FAO publication

[9] Ibe S.N (1999): Livestock production in the South-East Zone: Prospects and Strategies in the new millennium. An invited paper presented at the $14^{\text {th }}$ Annual South-East Zonal Farming system Research and Extension workshopheld at the Michael Okpara Auditorium, Umuahia Abia State, Nigeria. Nov, 9-12, 1999.

[10] KayRonald. D (1981): Farm Management: Planning, Control and Implementation. McGraw-Hill Kogakusha, Ltd . 
[11] Mbanasor J.A., Nwosu A.C. (2003): Livestock sector in the Nigerian Economy:Policy-Direction. Journal of Agricultural and Food Science 1(2): 141-147.

[12] Ohajianya D.O., Oguoma N.O (2009): Optimum cropping patterns under Limited Resource conditions: A micro-level study in Imo state, Nigeria. Pakistan Journal of Social Sciences; 6(1):36-41.
[13] Olawunmi A.T. ET AL. (2010): Economic Analysis of Homestead Fish Production in Ogun State, Nigeria Journal of Human Ecology; 31(1):13-17.

[14] Onuekwusi G.C (2001): Adoption of improved rabbit technology by farmers in Akwa- Ibom state, Nigeria-implication for extension. Proceedings of $36^{\text {th }}$ Annual conference, Agric society of Nigeria F.U.T. Owerri. Oct. 20-24, pp:368-371. 